\title{
Effects of iron toxicity on germination and initial growth of Carica papaya $\mathrm{L}$.
}

Efeitos da toxicidade por ferro na germinação e crescimento inicial de Carica papaya L.

\author{
J. Rodrigues Filho*; V. B. Corte; I. T. A. L. Perin; C. R. dos Santos; R. W. da \\ Silva
}

Departamento de Ciências Biológicas/Laboratório de Interações Vegetais/Setor Botânica, Universidade Federal do Espírito Santo, 29075-910, Vitória-ES, Brasil

josinei.rf@hotmail.com

(Recebido em 20 de maio de 2020; aceito em 12 de outubro de 2020)

\begin{abstract}
Iron $(\mathrm{Fe})$ is vital for plant development. Its excessive is harmful, both to forest and cultivated species. This study analyzed the effect of high Fe doses on the germination and initial growth of Carica papaya seeds, submitted to concentrations of $0.045,4$, and $8 \mathrm{mM}$ in the form of ferrous sulfate and FeEDTA. Germination percentage, germination speed index, shoot and root growth, fresh and dry mass of the seeds were analyzed. For the initial growth the following variables were analyzed: leaf area, stem and root growth, fresh and dry mass, quantification of chloroplastid pigments, analysis of chlorophyll a fluorescence, element contents and the activity of the enzymes Superoxide Dismutase, Catalase and Peroxidase. Fe stress affected the percentage and speed of germination, root growth, and the accumulation of biomass of $C$. papaya, with FeEDTA being responsible for the most pronounced effects. Fe led to increases in chlorophyll and photosynthetic performance without changes in carotenoid levels. The $8 \mathrm{mM}$ treatments impaired root growth, aerial growth, leaf area expansion, and biomass accumulation. The increase in Fe concentration led to an increment in its deposition in root tissue, with a drop in potassium levels in the $8 \mathrm{mM}$ treatment. There was an increase in Peroxidase activity when submitted to FeEDTA. There was no difference in Superoxide Dismutase and Catalase expression in any treatment. These results show the sensitivity of $C$. papaya species to toxic levels of $\mathrm{Fe}$, which caused damage to metabolism and initial growth.

Keywords: seed, metal, stress
\end{abstract}

O ferro $(\mathrm{Fe})$ é vital para o desenvolvimento das plantas. Seu excesso é prejudicial para espécies florestais e cultivadas. Este estudo analisou o efeito de altas doses de Fe na germinação e desenvolvimento inicial de Carica papaya, submetidas a concentrações de $0,045,4$ e $8 \mathrm{mM}$ na forma de sulfato ferroso e FeEDTA. Porcentagem de germinação, índice de velocidade de germinação, comprimento aéreo e radicular e massa fresca e seca das sementes foram analisadas. Para o desenvolvimento inicial as seguintes variáveis foram analisadas: área foliar, comprimento do caule e raiz, massa fresca e seca, quantificação de pigmentos cloroplastídeos, análise da fluorescência da clorofila a, conteúdo dos elementos, e atividade das enzimas Superoxido Dismutase, Catalase e Peroxidase. O estresse por Fe afetou a porcentagem e velocidade de germinação, crescimento radicular e acúmulo de biomassa de $C$. papaya, sendo o FeEDTA responsável pelos efeitos mais pronunciados. O Fe levou a aumentos no teor de clorofila e no desempenho fotossintético sem alterações nos carotenóides. Os tratamentos com $8 \mathrm{mM}$ afetaram o crescimento radicular e aéreo, expansão da área foliar e acúmulo de biomassa. $\mathrm{O}$ aumento na concentração de $\mathrm{Fe}$ acarretou uma maior deposição no tecido radicular, com queda nos níveis de potássio no tratamento $8 \mathrm{mM}$. Houve aumento na atividade da Peroxidase quando submetido ao FeEDTA. Não houve diferença na expressão da Superóxido dismutase e Catalase. Estes resultados mostram a sensibilidade da espécie $C$. papaya ao $\mathrm{Fe}$, causando danos ao metabolismo e desenvolvimento inicial.

Palavras chave: semente, metal, estresse

\section{INTRODUCTION}

Mining and processing of $\mathrm{Fe}$ are today one of the most important economic activities in southeastern Brazil, especially in the states of Minas Gerais and Espírito Santo [1]. However, the extraction of this mineral generates problems such as the production of non-biodegradable waste which affects both the environment near the extraction and beneficiation area and surrounding regions that may be directly or indirectly linked to production [2]. 
Toxicity caused by increased Fe concentration is characterized by the accumulation of this metal in all plant tissues, causing foliar chlorotic stains, loss in photosynthetic efficiency, enzymatic disturbances, a deficit in biomass accumulation, and decrease in growth and fruiting rate in cultivated species [3, 4].

Losses caused by the increased Fe content in the productivity of these species is a concern that dates back to the middle of the $20^{\text {th }}$ century when excess $\mathrm{Fe}$ was verified in Asia in rice plantations [3]. Other works relating $\mathrm{Fe}$ stress to the production of cultivated plants include Nicotiana tabacum L. [5], Lactuca sativa L. and Eruca sativa Mill. [6], Glycine max L. Merrill [7] and Coffea spp L. [8].

The species Carica papaya is a tropical fruit tree known by the common name papaia and presents notorious importance in the national economic scenario. The culture occurs in many states of the country, and the city of Linhares, Espírito Santo (Brazil), presents a significant contribution to the national production $[9,10]$, with 60 thousand tons of fruit sold in the country per year [11].

The city of Linhares is cut by watercourses that historically suffer from an accumulation of heavy metals, especially Fe [12, 13]. In 2015, Linhares main river suffered with the accumulation of Fe due to the disaster of Mariana, in the state of Minas Gerais. Studies confirmed that more than 40 million cubic meters of Fe-rich waste contaminated the environment, limiting the crop productivity of this species [14].

The study of $C$. papaya as an indicator of environmental quality is essential, not only because it has a wide distribution in areas affected by Fe accumulation [15], but also because it is a widely cultivated, commercialized and consumed species in Brazil. This study analyzed the effects of excess $\mathrm{Fe}$ on the germination and initial growth of the species $C$. papaya.

\section{MATERIALS AND METHODS}

Seeds of $C$. papaya, Sunrise solo variety, were stored in the Plant Interactions Laboratory of the Federal University of Espírito Santo in Vitória (ES) in a cold chamber $\left(5^{\circ} \mathrm{C}\right)$. Four treatments (two Fe sources and two concentrations) plus a control treatment, were tested for germination and initial growth. The concentrations used were 0.045 (control), $4 \mathrm{mM}$, and $8 \mathrm{mM}$, applied in the form of ferrous sulfate $\left(\mathrm{FeSO}_{4}\right)$, and FeEDTA. The experimental design was entirely randomized, with four repetitions of 25 seeds for the germination test and 20 plants per treatment for the analysis of initial growth. The means obtained from the treatments were compared using an analysis of variance (ANOVA) and the Tukey test at 5\% significance. All statistical analyses used the Sisvar program version 5.7.

\section{Germination Test}

Seeds were disinfected with $2 \%$ sodium hypochlorite for 2 minutes, washed and sown in Petri dishes. Then, seeds were lined with two sheets of filter paper moistened with $\mathrm{FeSO}_{4}$ and FeEDTA solutions corresponding to each treatment [16]. The germination tests were run in a B.O.D. germination chamber, under a constant temperature of $25^{\circ} \mathrm{C}$ and $12 / 12 \mathrm{~h}$ photoperiod. Germination was monitored daily, considering germinated seeds with radicle protrusion of at least $2 \mathrm{~mm}$ [17]. The germination percentage (\%G), germination speed index (GSI) [18], root and aerial part growth $(\mathrm{cm})[19]$ and fresh and dry masses $(\mathrm{g})$ were analyzed [20].

\section{Initial growth analysis}

Twenty days old plants, growing in unfertilized substrate plus washed sand in a 1:1 ratio, were submitted to the respective treatments with Fe solutions applied via soil. It was analyzed the antioxidant enzyme activity, chloroplastid pigments, chlorophyll a fluorescence, growth measures and elements content. Plants grew under a constant temperature of $25^{\circ} \mathrm{C}$ and $12 / 12 \mathrm{~h}$ photoperiod and were maintained in Hoagland solution at ionic half strength and $\mathrm{pH} 5.0$ [21]. 


\section{Antioxidant enzyme activities}

The activity of the antioxidant enzymes Superoxide Dismutase (SOD), Peroxidase (POX), and Catalase (CAT) was verified twenty days after the Fe application via soil. For the extraction of the enzymes, $300 \mathrm{mg}$ of root plant material was homogenized with $0.1 \mathrm{M}$ potassium phosphate buffer (pH 6.8), $0.1 \mathrm{mM} \mathrm{EDTANa}^{2}$, and $1 \%$ polyvinylpolypyrrolidone (PVPP). The extractions were performed using mortar and pistil with liquid nitrogen. The material was centrifuged at $12000 \mathrm{xg}$ for $15 \mathrm{~min}$ at $4{ }^{\circ} \mathrm{C}$. The supernatant was used for the SOD, CAT and POX tests. SOD activity was verified at $25^{\circ} \mathrm{C}$ in a $15 \mathrm{~W}$ lamp-lit chamber, based on Del Longo et al. (1993) [25], Giannopolitis and Ries (1977) [26], and Beauchamp and Fridovich (1971) [27]. After 6 minutes of exposure, a $560 \mathrm{~nm}$ reading was performed; the measured of POX activity was according to Kar and Mishra (1976) [28] and Chance and Maehley (1955) [29], and the reaction occurred at room temperature for 2 minutes following the $420 \mathrm{~nm}$ reading, and the CAT activity followed the Havir and Mchale (1987) [30] and Anderson, Prasad and Stewart (1995) [31] protocol, and occurred at room temperature with a $240 \mathrm{~nm}$ reading for 2 minutes. The design used was entirely randomized with three repetitions with duplicates, according to Peixoto et al. (1999) [32].

\section{Extraction and quantification of chloroplastid pigments}

The chlorophyll a, b, and carotenoid contents were verified twenty days after the Fe application via soil, using three replicates with $20 \mathrm{mg}$ of fresh foliar mass each, homogenized in $5 \mathrm{~mL}$ of icy (80\%) acetone. After that, the material was filtered using a funnel and filter paper, and the filtered liquid was then stored in a $10 \mathrm{ml}$ volumetric flask wrapped in aluminum foil and PVC. The pigments were quantified using a spectrophotometer (Genesys 10S UV-Vis, Thermo Fisher Scientific, Waltham, USA) at wavelengths of 470, 645, and $662 \mathrm{~nm}$. according to Lichtenthaler (1987) [22].

\section{Chlorophyll a fluorescence}

Simultaneously with the pigment content, the chlorophyll fluorescence was also quantified using a Handy-PEA (Photosynthetic Efficiency Analyser) Hansatech Instruments ${ }^{\circledR}$, King's Lynn, Norfolk, UK portable fluorometer. The measurements occurred on expanded young leaves of 10 plants per treatment, and previously adapted to 40 minutes of darkness using leaf clips for complete oxidation of the photosynthetic system. The results were presented in an electronic spreadsheet using the PEA Plus v1.11 software. From this analysis, it was calculated the density of photosynthetic reaction centers of the photosystem II (PSII) (RC/ABS), the efficiency with which electrons move $(\delta \mathrm{R} 0)$, the performance of the photosystem I (PSI) oxy reduction reactions $(\delta \mathrm{R} 0 /(1-\delta \mathrm{R} 0)$ and the overall performance of the plant (PIABS + PITOTAL). All are biophysical parameters that quantify the energy flow through the electron transport chain using the JIP test [23].

\section{Growth measures}

The growth of the plants was evaluated at 10 and 20 days after the application of Fe solutions, and the parameters used for the analysis were leaf area $\left(\mathrm{cm}^{2}\right)$, stem and root growth $(\mathrm{cm})$, and fresh and dry mass $(\mathrm{g})$.

\section{Element content with scanning microscopy}

Plants were dehydrated in a drying oven at $70{ }^{\circ} \mathrm{C}$ for three days. Then, the material was sectioned into leaf, stem, and root, which were then covered with gold for analysis by scanning electron microscopy and then analyzed by Energy Dispersive Spectroscopy (EDS) to detect the elements absorbed by their parts [24]. 


\section{RESULTS AND DISCUSSION}

Fe accumulation significantly affected the germination of C. papaya species, reducing $\% \mathrm{G}$, GSI, root growth, and dry biomass values of germinated seeds. FeEDTA treatment induced the most adverse effects on dry mass accumulation, with a 55\% drop in root weight and $42 \%$ in airborne weight when compared to control. The same treatment provided an $80 \%$ reduction in root growth and a significant delay in GSI, causing seeds to germinate $65 \%$ slower than the control. There was no difference in aerial growth between treatments (Table 1).

Table 1: Effects of Fe stress on germination percentage (\%G), germination speed index (GSI), root growth $(R G)$, aerial growth $(A G)$, fresh root mass (FRM), fresh aerial mass (FAM), dry root mass (DRM) and dry aerial mass (DAM) of Carica papaya seeds.

\begin{tabular}{lcccccccc}
\hline Treatment & $\% \mathrm{G}$ & GSI & RG(cm) & AG $(\mathrm{cm})$ & FRM(g) & FAM $(\mathrm{g})$ & DRM $(\mathrm{g})$ & DAM $(\mathrm{g})$ \\
\hline Control & $53 \mathrm{a}$ & $2.21 \mathrm{a}$ & $1.86 \mathrm{a}$ & $1.45 \mathrm{ab}$ & $0.0078 \mathrm{a}$ & $0.027 \mathrm{a}$ & $0.0035 \mathrm{a}$ & $0.0046 \mathrm{a}$ \\
$\mathrm{Fe}^{+2} 4 \mathrm{mM}$ & $41 \mathrm{~b}$ & $1.73 \mathrm{~b}$ & $1.50 \mathrm{a}$ & $1.60 \mathrm{a}$ & $0.0066 \mathrm{ab}$ & $0.024 \mathrm{a}$ & $0.0027 \mathrm{~b}$ & $0.0046 \mathrm{a}$ \\
$\mathrm{Fe}^{+2} 8 \mathrm{mM}$ & $40 \mathrm{~b}$ & $1.74 \mathrm{~b}$ & $0.54 \mathrm{~b}$ & $1.16 \mathrm{ab}$ & $0.0058 \mathrm{ab}$ & $0.020 \mathrm{ab}$ & $0.0011 \mathrm{c}$ & $0.0042 \mathrm{a}$ \\
Fe EDTA & $23 \mathrm{c}$ & $0.73 \mathrm{c}$ & $0.38 \mathrm{~b}$ & $0.82 \mathrm{~b}$ & $0.0043 \mathrm{~b}$ & $0.013 \mathrm{~b}$ & $0.0013 \mathrm{c}$ & $0.0028 \mathrm{~b}$ \\
$4 \mathrm{mM}$ & & & & & & & & \\
$\begin{array}{l}\text { Fe EDTA } \\
8 \mathrm{mM}\end{array}$ & $25 \mathrm{c}$ & $0.78 \mathrm{c}$ & $0.36 \mathrm{~b}$ & $0.80 \mathrm{~b}$ & $0.0032 \mathrm{~b}$ & $0.013 \mathrm{~b}$ & $0.0016 \mathrm{c}$ & $0.0027 \mathrm{~b}$ \\
\hline
\end{tabular}

Different letters in the same column indicate significant differences between treatments. $(\mathrm{p} \leq 0.05$, Tukey test).

Although $\mathrm{Fe}$ is essential to plant metabolism and participates in crucial processes such as photosynthesis, respiration and nitrogen fixation [33, 34], it's excess is harmful as it causes the production of $\mathrm{H}_{2} \mathrm{O}_{2}$ and other reactive oxygen species (ROS) that will, through oxidative stress, affect almost all cellular functions, including embryonic [35]. The elevation in the oxidation process is highly related to damage to proteins, DNA synthesis, and cell division [36]. Such processes are extremely stimulated after the soaking of seeds and may have been affected by exposure to $\mathrm{Fe}$. The seed is a stage in plant development that presents protection against a wide range of stresses. However, after soaking its sensitivity increases [37] and, in addition to the effects already mentioned, Fe (especially in its chelated version) and other metals can reduce the mitotic activity of the embryonic meristem and present clastogenic effects on chromosomes, as already described in studies involving cultivated species such as corn and sunflower [38, 39]. Fe is also able to directly block the transport of water for the soaking of seeds [40, 41]. This blockage causes direct damage to germination and germination speed, accumulates dangerously in the mitochondria, and thus harms the respiratory metabolism, which may explain the low accumulation of dry matter in FeEDTA treatments when compared to control [42, 43].

Carica papaya plants exposed to high doses of Fe showed a significant increase in POX activity in both concentrations of FeEDTA treatment. There was no alteration on the expression of CAT and SOD enzymes (Table 2).

In response to the accumulation of ROS generated by Fe, the plant's antioxidant mechanisms increase its activity to block possible metabolic damage caused by oxidation [44, 45, 46]. Among these mechanisms, SOD, CAT, and POX enzymes act in the biotransformation of ROS into less harmful compounds to the plant. SOD is the first defense barrier against ROS, while CAT acts almost exclusively on peroxysomes and plant mitochondria. POX have their sites of action preferentially on chloroplasts and cell walls, where they also contribute to the process of cell expansion via oxidation of phenolic compounds in the last step to the formation of lignin [47, 48, 49]. In this work, SOD and CAT activities did not differ between treatments, which does not seem to indicate the presence of significant oxidative stress. However, for POX, it was found that FeEDTA caused an increase in enzyme activity. Increases in its activity have already been 
described for other species of cultivars when stressed with Fe, such as Solanum tuberosum L. [50], Zea mays L. [51] and Oryza sativa L. [52, 53]. This fact suggests a certain degree of metabolic disorder in chloroplasts, where there is a higher activity of POXs enzymes and a higher allocation of Fe present in leaves, being, therefore, the organelle that will suffer the most adverse effects when under stress [54].

Table 2: Effects of Fe stress on the activity of the enzymes superoxide dismutase (SOD), peroxidase $(P O X)$ and catalase (CAT) in Carica papaya plants.

\begin{tabular}{lccc}
\hline Treatment & $\begin{array}{c}\text { SOD (unity. } \\
\left.\text { SOD g }{ }^{-1} \mathrm{DM}\right)\end{array}$ & $\begin{array}{c}\mathrm{CAT}\left(\mu \mathrm{mol} \mathrm{H} \mathrm{O}_{2}\right. \\
\left.\mathrm{min}^{-1} \mathrm{~g}^{-1} \mathrm{DM}\right)\end{array}$ & $\begin{array}{c}\mathrm{POX}(\mu \mathrm{mol} \text { POX } \\
\left.\mathrm{min}^{-1} \mathrm{~g}^{-1} \mathrm{DM}\right)\end{array}$ \\
\hline Control & $0.40 \mathrm{a}$ & $29.86 \mathrm{a}$ & $4.76 \mathrm{a}$ \\
$\mathrm{Fe}^{+2} 4 \mathrm{mM}$ & $0.38 \mathrm{a}$ & $36.19 \mathrm{a}$ & $9.13 \mathrm{a}$ \\
$\mathrm{Fe}^{+2} 8 \mathrm{mM}$ & $0.35 \mathrm{a}$ & $33.22 \mathrm{a}$ & $7.75 \mathrm{a}$ \\
$\mathrm{Fe}$ EDTA 4 mM & $0.36 \mathrm{a}$ & $47.42 \mathrm{a}$ & $19.20 \mathrm{~b}$ \\
Fe EDTA 8 mM & $0.33 \mathrm{a}$ & $36.41 \mathrm{a}$ & $13.50 \mathrm{~b}$ \\
\hline
\end{tabular}

When analyzing the chloroplastid pigments, no differences were found in carotenoid levels. However, the chlorophyll a concentration increased in all treatments, and this elevation was up to five times when exposed to FeEDTA $8 \mathrm{mM}$. The chlorophyll $\mathrm{b}$ content in the plants varied only when subjected to chelated Fe with a fourteen-fold increase when exposed to $8 \mathrm{mM}$ and compared to control (Table 3).

Table 3: Effects of Fe stress on chlorophyll $a, b$ and carotenoid concentrations of Carica papaya plants.

\begin{tabular}{lccc}
\hline Treatment & $\begin{array}{c}\text { Chlorophyll } a \\
\left(\mathrm{mg} \mathrm{g}^{-1} \mathrm{DM}\right)\end{array}$ & $\begin{array}{c}\text { Chlorophyll } b \\
\left(\mathrm{mg} \mathrm{g}^{-1} \mathrm{DM}\right)\end{array}$ & $\begin{array}{c}\text { Carotenoids } \\
\left(\mathrm{mg} \mathrm{g}^{-1} \mathrm{DM}\right)\end{array}$ \\
\hline Control & $1.50 \mathrm{a}$ & $0.80 \mathrm{a}$ & $0.70 \mathrm{a}$ \\
$\mathrm{Fe}^{+2} 4 \mathrm{mM}$ & $3.38 \mathrm{~b}$ & $1.30 \mathrm{a}$ & $1.07 \mathrm{a}$ \\
$\mathrm{Fe}^{+2} 8 \mathrm{mM}$ & $2.99 \mathrm{~b}$ & $1.01 \mathrm{a}$ & $0.78 \mathrm{a}$ \\
Fe EDTA 4 mM & $4.09 \mathrm{c}$ & $2.29 \mathrm{~b}$ & $1.02 \mathrm{a}$ \\
Fe EDTA 8 mM & $8.1 \mathrm{~d}$ & $11.37 \mathrm{c}$ & $0.82 \mathrm{a}$
\end{tabular}

Different letters in the same column indicate significant differences between treatments $(\mathrm{p} \leq 0.05$, Tukey test).

Chlorophylls a and $\mathrm{b}$ are the main pigments responsible for the capture of light energy that will start the photosynthetic process. It is common to use the concentration of these pigments as an indicator of the effects of several abiotic stresses, including Fe, on plants [55]. Such stresses may inhibit the synthesis of 5-aminolevulinic acid, the precursor molecule of chlorophyll, or increase the activity of the chlorophyllase enzyme, which in turn degrades the chlorophylls present [56]. Also, Fe can block reducing compounds and enzymes that will participate in the pigment biosynthesis route [57]. Nevertheless, in this study, there was a significant increase in chlorophyll levels. Few studies have shown a positive relationship between an increase in heavy metal content and an increase in the amount of chloroplastidic pigments, being restricted basically to green algae [58]. 
However, Ma et al. (2016) [59], analyzing the effects of different ferrous sulfate concentrations on the growth of Zea mays L., found that concentrations up to $500 \mathrm{mg} / \mathrm{kg}(\sim 4 \mathrm{mM})$ stimulated the increase in chlorophyll content. Other similar results showed in individuals of the Jatropha curcas L. species grown on a high Fe substrate and in young plants of Anadenanthera colubrina (Vell.) Brenan and Moringa oleifera Lam. in which increased pigment concentrations were observed [60, $61,62]$. This increase may be related to the investment of the plant in adaptation mechanisms, in which the increase in chlorophyll content can promote a faster recovery of photosynthetic activity when the plant returns to non-stress conditions [63]. Pigment content is closely related to photosynthetic quality, and any change in chlorophyll and carotenoid content can affect photosynthesis and plant productivity [57].

The analysis of the effects of high Fe levels on photosynthetic variables using the JIP test showed that there was no significant difference between the density values of active PSII reaction centers, nor the performance of the oxi-reduction reactions of the PSI (Figure 1). On the other hand, for all treatments, when compared to control, it was observed a significant increase in the locomotion efficiency of electrons and the overall performance of the plant (Figure 2).

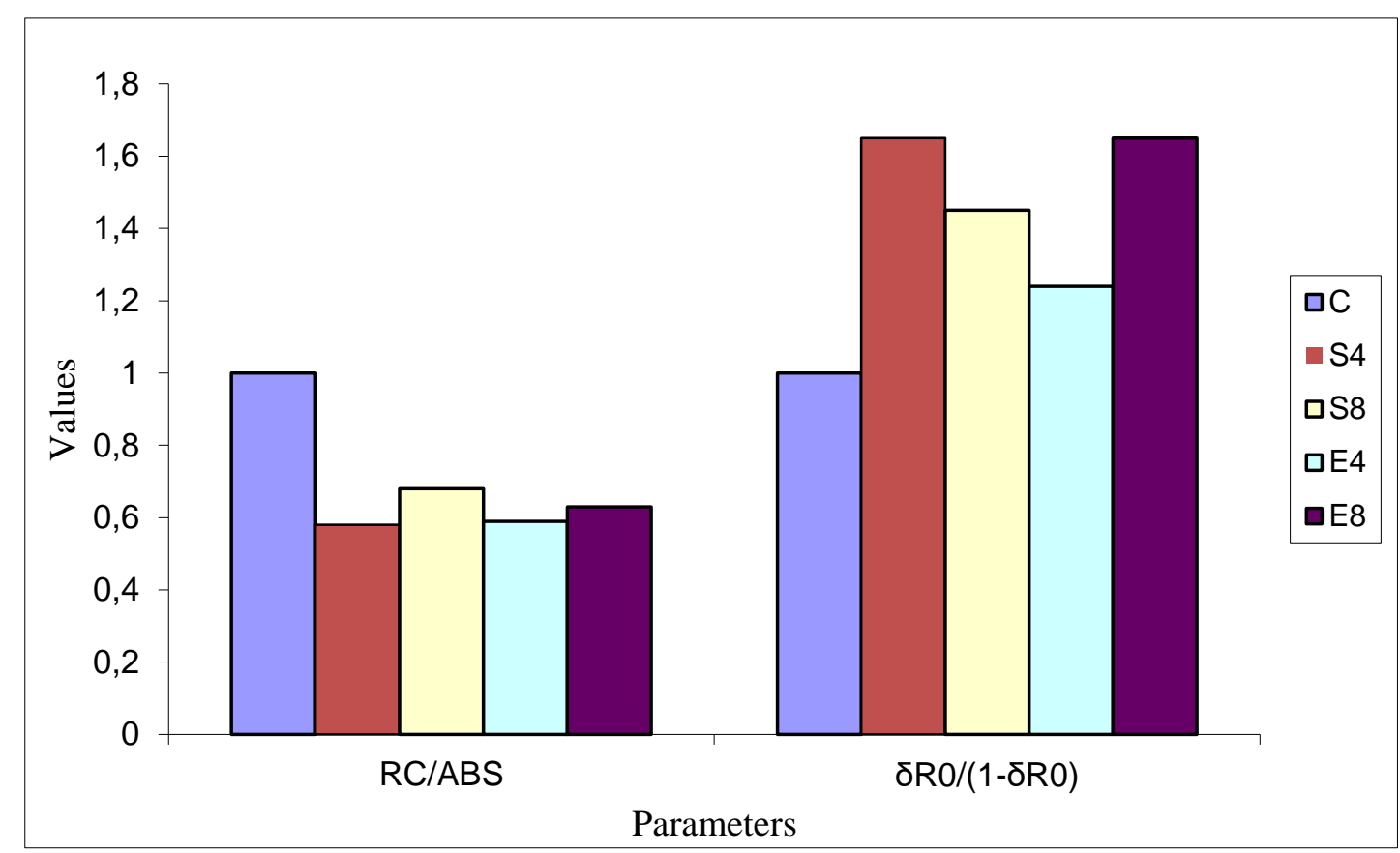

Figure 1: Effects of Fe stress on RC/ABS and $\delta R 0 /(1-\delta R 0)$ of C. papaya plants. (C): Control; $(S 4): F^{+2} 4$ mM; (S8): Fe +2 $^{+2}$ mM; (E4): FeEDTA 4 mM; (E8): FeEDTA 8 mM. (p $\leq 0.05$, Tukey test).

The increase in electron transport and the performance indexes of $C$. papaya plants were in line with the increase in the content of chloroplastid pigments. The increase in chlorophylls a and $\mathrm{b}$ concentration allowed a higher light uptake, which resulted in higher performance of both photosystems, without, however, need to raise the density of the reaction centers. Similar increases in electron transport and photosynthetic performance were found by Santos Junior (2018) [62] in his work with J. curcas L. plants equally exposed to high Fe contents in the soil during the initial development phase. Such results may indicate a tolerance of $C$. papaya species to Fe stress in their energy transport to the PSI. 


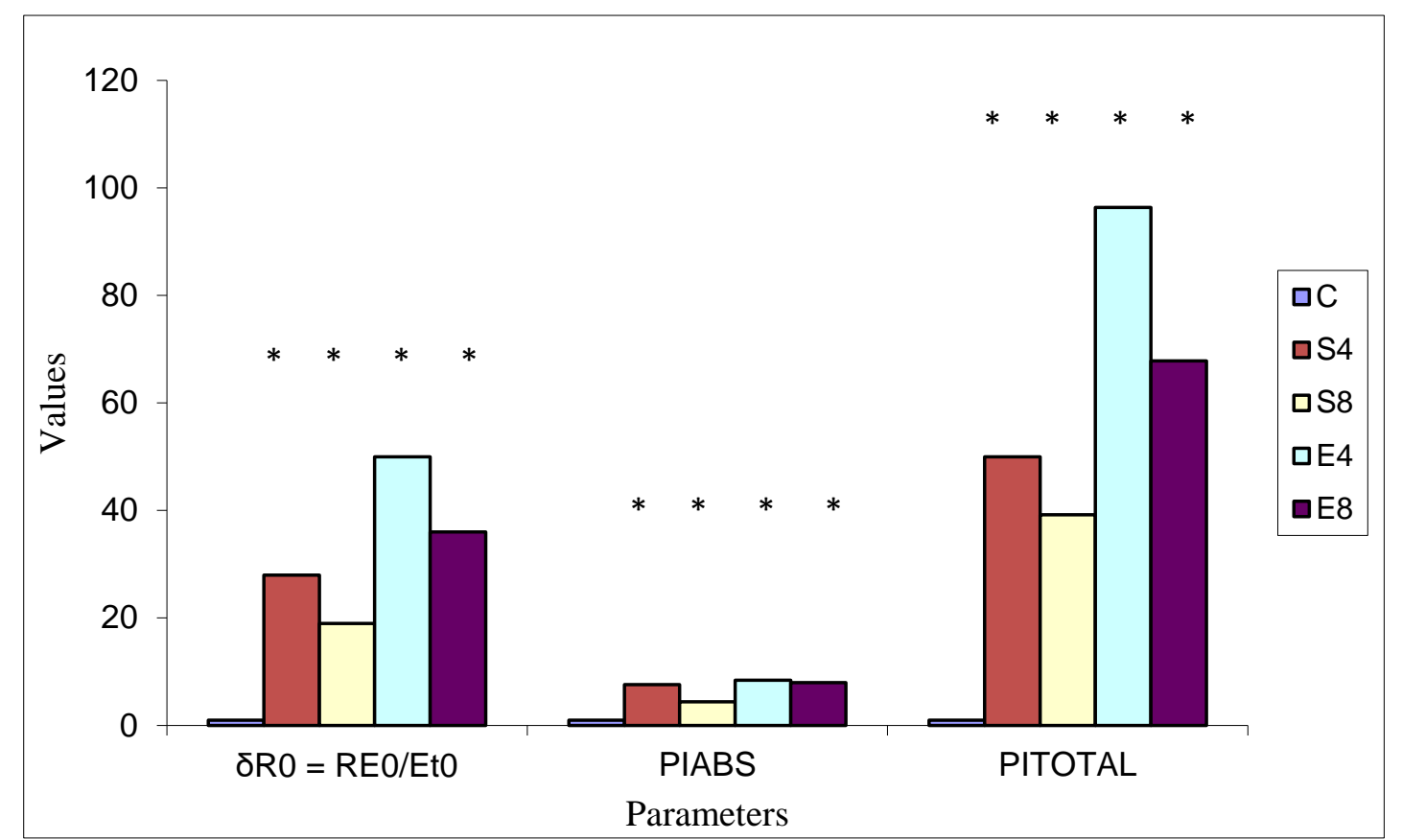

Figure 2: Effects of Fe stress on $\delta R 0=$ REO/ETO, PIABS and PITOTAL of C. papaya plants. (C): Control; (S4): $\mathrm{Fe}^{+2} 4 \mathrm{mM}$; (S8): $\mathrm{Fe}^{+2} 8 \mathrm{mM}$; (E4): FeEDTA $4 \mathrm{mM}$; (E8): FeEDTA 8 mM. Asterisk indicates significant difference between mean and control. $(p \leq 0.05$, Tukey test).

Exposure to Fe caused a decrease in root size, aerial part, leaf area, and biomass in both time evaluations, i.e., at 10 and 20 days of the experiment. Fe applied via solution to the soil showed inhibitory effects with both sources of the metal. It was observed near $80 \%$ drop in leaf area expansion at ten days compared to the control, on the $8 \mathrm{mM}$ concentration of the $\mathrm{Fe}^{+2}$ treatment. Similarly, although the same treatment did not provide reductions in root sizes and aerial part at the end of the experiment, it brought significant drops in dry mass accumulation of the aerial part at 10 and 20 days with decreases of $67 \%$ and $69 \%$ respectively. FeEDTA $8 \mathrm{mM}$ treatment showed even more considerable damage, with a $75 \%$ reduction in the dry mass of the aerial part, both at 10 and 20 days. Fe in its chelated form also caused reductions in leaf area measurements and root sizes (for treatment $8 \mathrm{mM}$ at 20 days) and aerial part in both time evaluations, when compared to control. Root dry mass values did not change between treatments (Table 4).

It was verified the deleterious effects of $\mathrm{Fe}$ on plants growth from the concentration of $4 \mathrm{mM}$ for the chelated form, and of $8 \mathrm{mM}$ for the ferrous sulfate. Other studies found similar damage caused by $\mathrm{Fe}$ excess in plant development. Eugenia uniflora L. plants exposed to high $\mathrm{Fe}$ concentrations showed a decrease in root growth, plant height, as well as accumulation of dry matter [46]. Neves (2004) [64], also working with E. uniflora L., observed a significant decrease in branches and leaves numbers, stem and roots growth, and root volume of plants subjected to stress by ferric citrate. In cultivated species, the same effects on growth were verified in Oryza sativa L., Ipomoea batatas (L.) Lam., and Vigna radiata (L.) R. Wilczek [3, 47, 34]. The toxic effects of Fe may be related to its efficiency in inactivating several key enzymes of plant metabolism, which will culminate in blocking protein and DNA synthesis, as well as causing nutritional disorders $[65,66]$. Additionally, Fe can act by reducing the availability of the reducing power of $\mathrm{NADPH}_{2}$ and ATP or causing an imbalance in the enzymes involved in fixing atmospheric $\mathrm{CO}_{2}$ in the Calvin cycle. In the photosynthetic stage, $\mathrm{Fe}$ has already demonstrated the ability to interfere negatively in the process of stomach opening, which will lead to a reduction in the diffusion of $\mathrm{CO}_{2}$ to mesophiles and a decrease in the activity of the carboxylation phase of photosynthesis [45, 67]. These Fe capacities may explain the non-elevation of the oxi-reduction reactions of the PSI, added to the decrease in the growth rate of the plants, despite the increase in pigment content and photosynthetic performance. 
Table 4: Effects of Fe stress on root growth (Root), stem growth (Stem), leaf area (LA), fresh root mass (FRM), fresh aerial mass (FAM), dry root mass (DRM) and dry aerial mass (DAM) of C. papaya plants at 10 and 20 days after the beginning of treatments.

\begin{tabular}{|c|c|c|c|c|c|c|c|c|c|c|c|c|c|c|}
\hline \multirow{2}{*}{ Treatment } & \multicolumn{2}{|c|}{$\operatorname{Root}(\mathrm{cm})$} & \multicolumn{2}{|c|}{ Stem $(\mathrm{cm})$} & \multicolumn{2}{|c|}{$\mathrm{LA}\left(\mathrm{cm}^{2}\right)$} & \multicolumn{2}{|c|}{ FRM (g) } & \multicolumn{2}{|c|}{ DRM (g) } & \multicolumn{2}{|c|}{ FAM (g) } & \multicolumn{2}{|c|}{$\operatorname{DAM}(\mathrm{g})$} \\
\hline & $10 \mathrm{~d}$. & $20 \mathrm{~d}$. & $10 \mathrm{~d}$. & $20 \mathrm{~d}$ & $10 \mathrm{~d}$. & $20 \mathrm{~d}$. & $10 \mathrm{~d}$. & $20 \mathrm{~d}$. & $10 \mathrm{~d}$. & $20 \mathrm{~d}$. & $10 \mathrm{~d}$. & $20 \mathrm{~d}$. & $10 \mathrm{~d}$. & $20 \mathrm{~d}$ \\
\hline Control & $2.88 \mathrm{a}$ & $3.34 \mathrm{a}$ & $4.62 \mathrm{a}$ & $4.84 a$ & $2.70 \mathrm{a}$ & $3.17 \mathrm{a}$ & $0.047 \mathrm{a}$ & $0.068 \mathrm{a}$ & $0.0015 \mathrm{a}$ & $0.0029 a$ & $0.147 \mathrm{a}$ & $0.150 \mathrm{a}$ & $0.0110 \mathrm{a}$ & $0.0160 \mathrm{a}$ \\
\hline $\mathrm{Fe}^{+2} 4 \mathrm{mM}$ & $2.36 \mathrm{ab}$ & $3.26 \mathrm{a}$ & $3.58 \mathrm{~b}$ & $4.58 \mathrm{a}$ & $0.85 b$ & $2.95 \mathrm{ab}$ & $0.028 \mathrm{ab}$ & $0.064 \mathrm{a}$ & $0.0016 \mathrm{a}$ & $0.0021 \mathrm{a}$ & $0.054 b$ & $0.130 \mathrm{a}$ & $0.0041 b$ & $0.0130 \mathrm{a}$ \\
\hline $\mathrm{Fe}^{+2} 8 \mathrm{mM}$ & $0.86 b$ & $2.38 \mathrm{ab}$ & $2.90 \mathrm{bc}$ & $4.52 \mathrm{a}$ & $0.44 \mathrm{c}$ & $1.95 b c$ & $0.011 b$ & $0.036 b$ & $0.0014 a$ & $0.0023 a$ & $0.038 b$ & $0.070 \mathrm{ab}$ & $0.0037 b$ & $0.0050 \mathrm{~b}$ \\
\hline $\begin{array}{c}\text { Fe EDTA } 4 \\
\text { mM }\end{array}$ & $2.08 \mathrm{ab}$ & $2.32 \mathrm{ab}$ & $2.96 b c$ & $2.70 \mathrm{~b}$ & $0.64 b c$ & $0.96 \mathrm{c}$ & $0.026 \mathrm{~b}$ & $0.030 \mathrm{~b}$ & $0.0014 \mathrm{a}$ & $0.0026 a$ & $0.046 \mathrm{~b}$ & $0.044 b$ & $0.0030 \mathrm{~b}$ & $0.0054 b$ \\
\hline $\begin{array}{c}\text { Fe EDTA } 8 \\
\text { mM }\end{array}$ & $2.26 \mathrm{ab}$ & $1.96 \mathrm{~b}$ & $2.52 \mathrm{c}$ & $2.68 b$ & $0.55 c$ & $1.03 \mathrm{c}$ & $0.018 b$ & $0.031 b$ & $0.0010 \mathrm{a}$ & $0.0023 a$ & $0.040 \mathrm{~b}$ & $0.034 b$ & $0.0026 b$ & $0.0041 b$ \\
\hline
\end{tabular}

Different letters in the same column indicate significant differences between treatments. ( $\mathrm{p} \leq 0.05$, Tukey test). 
The content of constituent elements analysis after 20 days, showed little Fe translocation to the aerial part. It was verified the highest metal contents in the roots of plants submitted to treatments of $8 \mathrm{mM}$ in sulfate form and EDTA, with $4.12 \%$ and $3.45 \%$ of dry weight, respectively, which corresponds to an increase of $250 \%$ in root Fe levels when compared to treatments in the $4 \mathrm{mM}$ concentration (Supplementay file). The high Fe levels present in the root region may be part of a strategy observed in some plants, which consists in the allocation of Fe in the vacuole of nonphotosynthesizing tissues or with low production, aiming at protecting the primary metabolism [68, 69]. This process is concomitant with other mechanisms that, in an attempt to block the entrance of the metal, modify the $\mathrm{pH}$ of the region close to the root, favoring the oxidation of $\mathrm{Fe}^{+2}$ in nonabsorbable $\mathrm{Fe}^{+3}$, causing the formation of $\mathrm{Fe}$ plates [70].

In the same root region, it was possible to notice the potassium (K) levels at doses of $8 \mathrm{mM}$ dropped $70 \%$ in ferrous sulfate and 50\% in chelated Fe, compared to the control (Supplementay file $\mathrm{F}$ and J). Stress, whether biotic or abiotic, is a recognized agent disturbing the metabolism of $\mathrm{K}[71,72]$. Also, it is known that high Fe concentrations affect the balance of various ions, especially K [73]. Some studies show the proportional relationship between high Fe levels and significant ion loss [74, 75, 76, 77]. Excess Fe leads to the formation and accumulation of nitric oxide (NO) in root cells, and NO production responds significantly to increased exposure to $\mathrm{Fe}[78$, 79]. NO can stimulate the activation of non-selective cationic channels (NSCCs), which are primarily responsible for $\mathrm{K}$ efflux [73, 80]. $\mathrm{K}$ is an essential osmotic cell activator, acting crucially in opening and closing the stomach and in protein synthesis. The drop in its content in $8 \mathrm{mM}$ treatments may be one of the possible causes of the damage that compromised the growth of $C$. papaya.

\section{CONCLUSIONS}

$\mathrm{Fe}$, both in its reduced and chelated form, strongly inhibits germination, germination speed, root growth, and the accumulation of biomass of $C$. papaya seeds. FeEDTA can stimulate the activity of the enzyme POX, but without indications of oxidative stress in $C$. papaya plants. High Fe content causes elevation of chlorophyll a, b, and photosynthetic performance of $C$. papaya, but affected initial growth with a decrease in the size of the radicle, aerial part, leaf area, accumulation of biomass, and levels of $\mathrm{K}$. Thus, the productivity of this species is severely limited in areas affected by Fe accumulation.

\section{REFERENCES}

1. Espindola HS, Nodari ES, Santos MAD. Rio Doce: riscos e incertezas a partir do desastre de Mariana (MG). Rev Bras Hist. 2019 Jul;39(81):141-162, doi: 10.1590/1806-93472019v39n81-07.

2. Silva GP, Fontes MPF, Costa LM, Venegas VHA. Potencialidade de plantas para revegetação de estéreis e rejeito da mineração de ferro da mina de alegria, Mariana-MG. Pesq Agropec Trop. 2006 Sep;36(3):165172.

3. Ahlert RJ. Análise proteômica diferencial em raízes de plântulas de arroz (Oriza sativa L.) submetidas ao estresse por ferro [dissertation]. Pelotas (RS): Universidade Federal de Pelotas; 2010. 82 p.

4. Barbosa MR, Araújo Silva MM, Willadino L, Ulisses C, Rangel Camara T. Geração e desintoxicação enzimática de espécies reativas de oxigênio em plantas. Ciênc Rural. 2014 Mar;44(3):453-460, doi: 10.1590/S0103-84782014000300011.

5. Kampfenkel K, Van Montagu M, Inzé D. Effects of iron excess on Nicotiana plumbaginifolia plants (implications to oxidative stress). Plant Physiol. 1995 Mar;107(3):725-735, doi: 10.1104/pp.107.3.725.

6. Laurett L, Fernandes AA, Schmildt ER, Almeida CP, Pinto MLPB. Desempenho da alface e da rúcula em diferentes concentrações de ferro na solução nutritiva. Rev Cienc Agrar. 2017 Jan;60(1):45-52, doi: $10.4322 /$ rca.2466.

7. Bataglia OC, Mascarenhas HAA. Toxicidade de ferro em soja. Bragantia. 1981 Jul;40(1):199-203.

8. Krohling CA, Eutrópio FJ, Figueira FF, Campostrini E, Dobbss LB, Ramos AC. Níveis tóxicos de ferro em lavouras de café conilon (Coffea canephora L.) em solos de tabuleiros costeiros. Coffee Sci. 2016 Apr;11(2):255-266.

9. Martins D, Costa A. A cultura do mamoeiro: tecnologias de produção. Vitória: Incaper; 2003. 497 p. 
10. de Lima JF, Peixoto CP, da Silva Ledo CA. Índices fisiológicos e crescimento inicial de mamoeiro (Carica papaya L.) em casa de vegetação. Ciênc agrotec. 2007 Sep;31(5):1358-1363, doi: 10.1590/S1413-70542007000500013.

11. IBGE: Instituto Brasileiro de Geografia e Estatística. Produção Agrícola Municipal 2018 [Internet]. Rio de Janeiro (RJ): IBGE; 2019 - [acessed 2020 Feb 30]. Available from: https://cidades.ibge.gov.br/brasil/es/linhares/pesquisa/15/11863?indicador=11986\&ano=2018\&localida de $1=0 \&$ tipo $=$ ranking.

12. Wanderley LJ, Mansur MS, Milanez B, Pinto RG. Desastre da Samarco/Vale/BHP no Vale do Rio Doce: aspectos econômicos, políticos e socio ambientais. Ciênc Cult. 2016 Jul;68(3):30-35, doi: 10.21800/231766602016000300011

13. Canatto BF. Caracterização geoquímica dos sedimentos da bacia do Rio Gualaxo do Norte [monograph] Ouro Preto (MG): Universidade Federal de Ouro Preto; 2017. 83 p.

14. Viana JHM, Costa AM. A ciência do solo como instrumento para a recuperação das áreas afetadas pelo desastre de Mariana e dos solos na Bacia do Rio Doce. Soc Bras Ciênc Solo. 2016 Jan;42(1):24-27.

15. De Araújo ASF, Monteiro RTR. Indicadores biológicos de qualidade do solo. Biosci J. 2007 Jul; 23(3):6675.

16. Ferreira AG, Borghetti F. Germinação: do básico ao aplicado. Porto Alegre: Artmed; 2005. 323 p.

17. Brasil. Ministério da Agricultura, Pecuária e Abastecimento. Regras para análise de sementes. Brasília: Mapa/ACS; 2009. 399 p.

18. Maguire JD. Speed of germination-aid in selection and evaluation for seedling emergence and vigor. Crop Sci. 1962;2(2):176-177, doi: 10.2135/cropsci1962.0011183X000200020033x.

19. Formagio ASN, Masetto TE, Baldivia DS, Vieira MC, Zarate NAH, Pereira ZV. Potencial alelopático de cinco espécies da família Annonaceae. Rev Bras Bioci. 2010 Oct;8(4):349-354.

20. Echer FR, Dominato JC, Creste JE. Absorção de nutrientes e distribuição da massa fresca e seca entre órgãos de batata-doce. Hortic Bras. 2009 Jun;27(2):176-182, doi: 10.1590/S0102-05362009000200010.

21. Hoagland DR, Arnon DI. The waterculture method for growing plants without soil. Berkeley: Agric Exp Stn; $1950.31 \mathrm{p}$.

22. Lichthentaler HK. Chlorophyll and carotenoids-pigments of photosynthetic biomembranes. Method Enzymol. 1987;148:350-382, doi: 10.1016/0076-6879(87)48036-1.

23. Strasser BJ, Strasser RJ. Measuring fast fluorescence transients to address environmental questions: The JIP-test. In: Mathis P, editor. Photosynthesis: from 74 Light to Biosphere. Proceedings of the 10th International Photosynthesis Congress; 1995 Aug 20-25; Montpellier, France. Dordrecht: Kluwer Academic Publishers; 1995. p. 977-980, doi: 10.1007/978-94-009-0173-5_1142.

24. Dedavid BA, Gomes CI, Machado G. Microscopia eletrônica de varredura: aplicações e preparação de amostras: materiais poliméricos, metálicos e semicondutores. Porto Alegre: EdiPUCRS; 2007.60 p.

25. Del Longo OT, Goinzlez CA, Pastori GM, Trippi VS. Antioxidant defenses under hyperoxygenic and hyperosmotic conditions in leaves of two lines of maize with differential to drought. Plant Cell Physiol. 1993 Oct;37(7):1023-1028, doi: 10.1093/oxfordjournals.pcp.a078515.

26. Giannopolitis CN, Ries SK. Superoxide dismutases: Occurrence in higher plants. Plant Physiol. 1977 Feb;59(2):309-314, doi: 10.1104/pp.59.2.309.

27. Beauchamp C, Fridovich I. Superoxide Dismutase: Improved Assays and an Assay Applicable to Acrylamide Gels. Anal Biochem. 1971 Nov;44(1):276-287, doi: 10.1016/0003-2697(71)90370-8.

28. Kar M, Mishra D. Catalase, peroxidase, and polyphenoloxidase activities during rice leaf senescence. Plant Physiol. 1976 Feb;57:315-319, doi: 10.1104/pp.57.2.315.

29. Chance B, Maehley AC. Assay of catalases and peroxidases. Method Enzymol. 1955 Jan;2:764-775, doi: 10.1016/S0076-6879(55)02300-8.

30. Havir EA, McHale NA. Biochemical and developmental characterization of multiple forms of catalase in tobacco-leaves. Plant Physiol. 1987 Jun;84(2):450-455, doi: 10.1104/pp.84.2.450.

31. Anderson MD, Prasad TK, Stewart CR. Changes in isozyme profiles of catalase, peroxidase, and glutathione reductase during acclimation to chilling in mesocotyls of maize seedlings. Plant Physiol. 1995 Dec;109(4):1247-1257, doi: 10.1104/pp.109.4.1247.

32. Peixoto PHP, Cambraia J, Sant'anna R, Mosquim PR, Moreira MA. Aluminum effects on lipid peroxidation and on the activities of enzymes of oxidative metabolism in sorghum. Rev Bras Fisiol Veg. 1999 Jan;11(3):137-143.

33. Broadley M, Brown PIC, Rengel Z, Zhao F. Function of nutrients: micronutrients. 3rd ed. Amsterdam (Netherlands): Elsevier Academic Press; 2012. Chapter 7, Marschner's Mineral Nutrition of Higher Plants; p. 191-248, doi: 10.1016/C2009-0-63043-9.

34. Verma L, Pandey, N. The Effect of Iron Toxicity on Seed Germinationand Early Seedling Growth of Green Gram (Vigna radiata L. Wilczek). Int. 2017 Aug;6(8):1427-1430. 
35. Ravet K, Touraine B, Boucherez J, Briat JF, Gaymard F, Cellier F. Ferritins control interaction between iron homeostasis and oxidative stress in Arabidopsis. Plant J. 2009 Feb;57(3):400-412, doi:10.1111/j.1365-313X.2008.03698.x.

36. Kobayashi T, Nishizawa NK. Iron uptake, translocation, and regulation in higher plants. Annu Rev Plant Biol. 2012 Jan;63:131-152, doi: 10.1146/annurev-arplant-042811-105522.

37. Li W, Khan MA, Yamaguchi S, Kamiya Y. Effects of heavy metals on seed germination and early seedling growth of Arabidopsis thaliana. Plant Growth Regul. 2005 May;46:45-50, doi: 10.1007/s10725005-6324-2.

38. Chakravarty B, Srivastava S. Toxicity of some heavy metals in vivo and in vitro in Helianthus annuus. Mutat Res. 1992 Dec;283(4):287-294, doi: 10.1016/0165-7992(92)90061-1.

39. Nagajyoti PC, Lee KD, Sreekanth TVM. Heavy metals, occurrence and toxicity for plants: a review. Environ Chem Lett. 2010 Jul;8:199-216, doi: 10.1007/s10311-010-0297-8.

40. Bewley JD, Black M. Physiology and biochemistry of seeds. New York: Springer-Verlag; 1983. 378p.

41. Wierzbicka M, Obidzinska J. The effect of lead on seed imbibition and germination in different plant species. Plant Sci. 1998 Oct;137(2):155-171, doi: 10.1016/S0168-9452(98)00138-1.

42. Nenova V. Effect of iron supply on growth and photosystem II efficiency of pea plants. Gen Appl Plant Physiol. 2006 Jan;32:81-90.

43. McDonald I, Sloan GC, Zijlstra AA, Matsunaga N, Matsuura M, Kraemer KE, Mehraban P, Zadeh AA, Sadeghipour HR. Iron toxicity in rice (Oryza sativa L.), under different potassium nutrition. Asian J Plant Sci. 2008 Mar;7(3):251-259, doi: 10.3923/ajps.2008.251.259.

44. Becana M, Moran JF, Iturbe-Ormaetxe I. Iron dependent oxygen free radical generation in plants subjected to environmental stress: toxicity and antioxidant protection. Plant Soil. 1998 Apr;201(1):137147.

45. Pereira EG. Efeitos fisiológicos e bioquímicos causados pela deposição de ferro particulado em Clusia hilariana, uma espécie de restinga [dissertation]. Viçosa (MG): Universidade Federal de Viçosa; 2006. 54 p.

46. Jucoski GO. Toxicidade de ferro e metabolismo antioxidativo em Eugenia uniflora L. [thesis]. Viçosa (MG): Universidade Federal de Viçosa; 2011.93 p.

47. Adamski JM. Respostas morfológicas de Ipomoea batatas L. em função da concentração de ferro [dissertation]. Pelotas (RS): Universidade Federal de Pelotas; 2011. 64 p.

48. Ozdemir F, Bor M, Demiral T, Türkan I. Effects of 24-epibrassinolide on seed germination, seedling growth, lipid peroxidation, proline content and antioxidative system of rice (Oryza sativa L.) under salinity stress. Plant Growth Regul. 2004 Mar;42(3):203-211.

49. Mittler, R. Oxidative stress, antioxidants and stress tolerance. Trends Plant Sci. 2002 Sep;7(9):405-410, doi: 10.1016/s1360-1385(02)02312-9.

50. Chatterjee C, Gopal R, Dube BK. Impact of iron stress on biomass, yield, metabolism and quality of potato (Solanum tuberosum L.) Sci. Hortic. 2006 Mar;108(1):1-6, doi: 10.1016/j.scienta.2006.01.004.

51. Kumar P, Tewari RK, Sharma PN. Modulation of copper toxicity-induced oxidative damage by excess supply of iron in maize plants. Plant Cell Rep. 2008 Feb;27(2):399-409, doi: 10.1007/s00299-007-04531.

52. Fang WC, Kao $\mathrm{CH}$. Enhanced peroxidase activity in rice leaves in response to excess of iron, copper and zinc. Plant Sci. 2000 Oct;158(1-2):71-76, doi: 10.1016/S0168-9452(00)00307-1.

53. Stein RRJ, Duarte GL, Spohr MG, Lopes SIG, Fett JP. Distinct physiological responses subjected to iron toxicity under field conditions. Annals of Applied Biology. 2009 Feb;154(2):269-277, doi: 10.1111/j.1744-7348.2008.00293.x.

54. Sperotto RA, Ricachenevsky FK, Stein RJ, Waldow VA, Fett JP. Iron stress in plants: dealing with deprivation and overload. Plant Stress. 2010 Jan;4(2):57-69.

55. Streit NM, Canterle LP, Do Canto MW, Hecktheuer LHH. As clorofilas. Ciênc. Rural. 2005 May;35(3):748-755, doi: 10.1590/S0103-84782005000300043.

56. Sacramento BL, Cruz TS, Silva LL, Mota KNAB, Azevedo Neto AD, Da Bahia R. Pigmentos e teores de solutos orgânicos em plantas de aguapé sob estresse salino. Enciclopédia Biosfera. 2014 Jul;10(18):33443354.

57. Chandra R, Kang H. Mixed heavy metal stress on photosynthesis, transpiration rate, and chlorophyll content in poplar hybrids. Forest Sci Technol. 2015 Jun;12(2):55-61, doi: 10.1080/21580103.2015.1044024.

58. Devi Prasad PV, Devi Prasad PS. Effects of cadmium, lead and nickel on three freshwater green algae. Water Air Soil Pollut. 1982 Apr;17:263-268, doi: 10.1007/BF00283156.

59. Ma B, Xu A, Zhang X, Wu L. Chlorophyll change and spectral response of maize seedling under iron stress. In: 2016 IEEE International Geoscience and Remote Sensing Symposium (IGARSS); 2016 Jul 1015; Beijing, China. [place unknown]: IEEE; 2016. p. 6397-6400, doi: 10.1109/IGARSS.2016.7730672. 
60. Rivas R, Oliveira MT, Santos MG. Three cycles of water deficit from seed to young plants of Moringa oleifera woody species improves stress tolerance. Plant Physiol Biochem. 2013 Feb;63:200-208, doi: 10.1016/j.plaphy.2012.11.026.

61. Oliveira MT, Dias CM, Frosi G, Santos MG. Different mechanisms drive the performance of native and invasive woody species in response to leaf phosphorus supply during periods of drought stress and recovery. Plant Physiol Biochem. 2014 Sep;82:66-75, doi: 10.1016/j.plaphy.2014.05.006.

62. Santos Junior RN. Fisiologia de acessos de Jatropha curcas L. cultivados em solo contendo lama do Rio Doce [dissertation]. Vitória (ES): Universidade Federal do Espírito Santo; 2018. 64 p.

63. Frosi G, Harand W, Oliveira MTD, Pereira S, Cabral SP, Montenegro AADA, Santos MG. Different physiological responses under drought stress result in different recovery abilities of two tropical woody evergreen species. Acta Bot Bras. 2017 Apr; 31(2):153-160, doi: 10.1590/0102-33062016abb0375.

64. Neves NR. Respostas fisiológicas e antioxidativas em plantas de Eugenia uniflora L. submetidas ao excesso de ferro e chuva ácida [dissertation]. Viçosa (MG): Universidade Federal de Viçosa; 2004. 37p.

65. Marschner H. Mineral nutrition of higher plants. London: Academic Press; 1995.890 p.

66. Pinto SDS, Souza AED, Oliva MA, Pereira EG. Oxidative damage and photosynthetic impairment in tropical rice cultivars upon exposure to excess iron. Sci Agric. 2016 May;73(3):217-226, doi:10.1590/0103-9016-2015-0288.

67. Pereira EG, Oliva MA, Rosado-Souza L, Mendes GC, Colares DS, Stopato CH, Almeida AM. Iron excess affects rice photosynthesis through stomatal and non-stomatal limitations. Plant Sci. 2013 Mar;201202:81-92, doi: 10.1016/j.plantsci.2012.12.003.

68. Engel K, Asch F, Becker M. Classification of rice genotypes based on their mechanisms of adaptation to iron toxicity. J Plant Nutr Soil Sci. 2012 Dec;175(6):871-881, doi: 10.1002/jpln.201100421.

69. Thomine S, Vert G. Iron transport in plants: better be safe than sorry. Curr Opin Plant Biol. 2013 Jun; 16(3): 322-327, doi: 10.1016/j.pbi.2013.01.003.

70. Wu LB, Shhadi M, Gregorio G, Matthus E, Becker M, Frei M. Genetic and physiological analysis of tolerance to acute iron toxicity in rice. Rice. 2014 May;7(8):1-12, doi: 10.1186/s12284-014-0008-3.

71. Demidchik V, Shabala SN, Coutts KB, Tester MA, Davies JM. Free oxygen radicals regulate plasma membrane $\mathrm{Ca}^{2+}$ and $\mathrm{K}^{+}$permeable channels in plant root cells. J Cell Sci. 2003 Jan;116(1):81-88, doi: $10.1242 /$ jcs.00201.

72. Demidchik V, Cuin TA, Svistunenko D, Smith SJ, Miller AJ, Shabala S, Sokolik A, Yurin V. Arabidopsis root $\mathrm{K}^{+}$efflux conductance activated by hydroxyl radicals: single-channel properties, genetic basis and involvement in stress-induced cell death. J Cell Sci. 2010 May;123(9):1468-79, doi: 10.1242/jcs.064352.

73. Zhang L, Li G, Wang M, Di D, Sun L, Kronzucker HJ, Shi W. Excess iron stress reduces root tip zone growth through nitric oxide-mediated repression of potassium homeostasis in Arabidopsis. New Phytol. 2018 Jul;219(1):259-274, doi: 10.1111/nph.15157.

74. Li H, Yang X, Luo AC. Ameliorating effect of potassium on iron toxicity in hybrid rice. J Plant Nutr. 2001;24(12):1849-1860, doi: 10.1081/PLN-100107598.

75. Li GJ, Xu WF, Kronzucker HJ, Shi WM. Ethylene is critical to the maintenance of primary root growth and $\mathrm{Fe}$ homeostasis under $\mathrm{Fe}$ stress in Arabidopsis. J Exp Bot. 2015 Apr;66(7):2041-54, doi: 10.1093/jxb/erv005.

76. Li GJ, Kronzucker HJ, Shi WM. Root developmental adaptation to Fe toxicity: mechanisms and management. Plant Signal Behav. 2016 Feb;11(1):e1117722, doi: 10.1080/15592324.2015.1117722.

77. Gao PP, Zheng GH, Wu YH, Liu P. Effect of exogenous potassium on photosynthesis and antioxidant enzymes of rice under iron toxicity. Russ J Plant Physiol. 2014 Jan;61:47-52, doi: 10.1134/S1021443714010051.

78. Arnaud N, Murgia I, Boucherez J, Briat JF, Cellier F, Gaymard F. An iron-induced nitric oxide burst precedes ubiquitin-dependent protein degradation for Arabidopsis AtFer1 ferritin gene expression. J Biol Chem. 2006 Aug;281(33):23579-88.

79. Touraine B, Briat JF, Gaymard F. GSH threshold requirement for NO-mediated expression of the Arabidopsis AtFer1 ferritin gene in response to iron. FEBS Lett. 2012 Mar;586(6):880-883, doi: 10.1016/j.febslet.2012.02.016.

80. Reyt G, Boudouf S, Boucherez J, Gaymard F, Briat JF. Iron and ferritin dependent ROS distribution impact Arabidopsis root system architecture. Mol Plant. 2014 Nov;8:439-453, doi: 10.1093/mp/ssu133. 